\title{
Neo-advocacy for Neo-liberal Times: Planning Aid and the Advocacy Project in England
}

Article

Accepted Version

Parker, G. and Street, E. (2017) Neo-advocacy for Neo-liberal Times: Planning Aid and the Advocacy Project in England.

Town Planning Review, 88 (4). pp. 443-463. ISSN 1478-341X doi: https://doi.org/10.3828/tpr.2017.28 Available at https://centaur.reading.ac.uk/69003/

It is advisable to refer to the publisher's version if you intend to cite from the work. See Guidance on citing.

To link to this article DOI: http://dx.doi.org/10.3828/tpr.2017.28

Publisher: Liverpool University Press

All outputs in CentAUR are protected by Intellectual Property Rights law, including copyright law. Copyright and IPR is retained by the creators or other copyright holders. Terms and conditions for use of this material are defined in the End User Agreement.

$\underline{\text { www.reading.ac.uk/centaur }}$

\section{CentAUR}


Central Archive at the University of Reading

Reading's research outputs online 


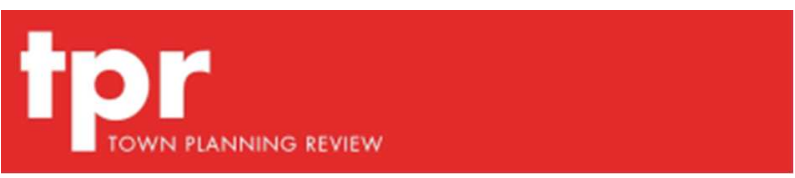

\section{Neo-advocacy for Neo-liberal Times: Planning Aid and the Advocacy Project in England}

\begin{tabular}{|r|l|}
\hline Journal: & Town Planning Review \\
\hline Manuscript ID & TPR-07-16-OA-0034.R2 \\
\hline Manuscript Type: & Original Article \\
\hline Keywords: & $\begin{array}{l}\text { advocacy, participation, spatial justice, education, planning aid, neo- } \\
\text { liberalism }\end{array}$ \\
& $\begin{array}{l}\text { The paper reviews the literature on advocacy planning and interweaves } \\
\text { empirical evidence drawn from participants in Planning Aid England to } \\
\text { reconsider its basis and effectiveness. Forms of 'neo-advocacy' planning } \\
\text { are deemed necessary given the continuing under-representation of lower } \\
\text { income groups and other minority groups in planning and in an era of neo- } \\
\text { liberal policy. The attention of policymakers and the planning profession } \\
\text { more widely should consider how neo-advocacy functions are sustained. It } \\
\text { is concluded that the aims of Planning Aid are so important to the } \\
\text { legitimacy and effectiveness of Planning that it needs to be placed on a } \\
\text { more secure footing. }\end{array}$ \\
\hline \multicolumn{2}{|l}{} \\
\hline
\end{tabular}




\section{Neo-advocacy for Neo-liberal Times: Planning Aid and the Advocacy Project in England.}

\section{Introduction}

Efforts to pluralise planning practice, to redress issues of exclusion and widen access to planning have involved a long-running search for ways to 'emancipate communities' (MacDonald, 2014; Matthews, 2013). Progress in extending participation in planning to those ends has been limited and while there are many examples of ideas and tools in circulation geared to enable participation (e.g. Brownill and Parker, 2010; Pemberton et al, 2015), there are numerous critiques of initiatives aimed at extending participation (e.g. Eversole, 2012; Sager, 2011; Miraftab, 2009; Bengs, 2005; Krumholz, 1994). Over fifty years ago advocacy planning was conceived as a means to represent and support sections of the population who were less able to participate effectively. In England a means to implement the ideas of advocacy planning proponents (e.g. Davidoff, 1965) was reflected in the creation of Planning Aid. This paper discusses the role, need and significance of advocacy planning in current times and reflects on the experience of Planning Aid England.

The paper recounts the findings of research involving a literature review, semi-structured interviews with Planning Aid England (PAE) staff and volunteers operating in one English region. All participants were anonymised as per the ethical undertakings provided at the time of data collection. The experiences of Planning Aid highlight how advocacy has been translated and manipulated, to reflect aspects of numerous planning theories. We do not seek to extend theoretical understandings of agonism (see Mouffe 1999; 2005; 2007; Pløger, 2004; Hillier, 2002; Gualini, 2015), nor the collaborative strand of theory (e.g. Forester, 1994; Healey, 2003; Huxley and Yiftachel, 2000; Benner and Pastor, 2015) here but it is useful to acknowledge these as relevant normative ideals and explanatory tools.

\section{Advocacy Planning - then and now}

Political theory since the 1970s has recognised calls to widen and deepen participation in local governance and provoked a concern with the redesign of institutions to enable this aim (Healey, 2003; Cleaver, 1999; Cleaver et al, 2001). Recently debates over the 'just city' and concerns over spatial justice (Soja, 2010; Fainstein, 2010; Benner and Pastor, 2015; Taylor and Edwards, 2016) have continued this trope. A major challenge appears to be how advocacy planning initiatives can play a role in operating between powerful interests and an empowered plural community. Studies that have looked carefully at the implementation of 
advocacy planning theory and practice have pointed to its limitations and the deep-rooted difficulties in solving the challenges that it has sought to address (Friedmann, 1987; Forester, 1994; Peattie, 1978; 1994; Neuman, 2000; Allmendinger, 2004; Gualini, 2015). Related discussions of dialogical and collaborative planning have led to calls for a more critical analysis of outcomes and to develop 'post-collaborative' participation - a strand which highlights the challenges involved, and the range of contexts and conditions that are producing and shaping participatory episodes (Brownill and Parker, 2010; Brownill, 2009). This potentially involves more agonistic approaches (Pløger, 2004; Hillier, 2002), while recognising that ultimately means of reconciliation are also required. As Benner and Pastor (2015) note, the apparently competing models of collaborative and advocacy planning may be applied and combined creatively both to develop knowledge and understanding and to hold powerful interests to account. Having said that how to actualise this remains unresolved.

The uneasy and limited acceptance of participatory engagement and the theoretical bases that promote participation efforts among public authorities or private developers can easily result in both fragile and precarious support for such activities and the intermediaries involved; given that they remain under-resourced and marginalised. Participatory spaces are often diluted or co-opted to serve the interests of the powerful, or designed to minimise perceived 'obstruction' to development and typically involve consultation exercises, and superficial adjustments to policy which can amount to a 'new tyranny' (Cleaver et al, 2001; Taylor, 2007) or reflect a 'symbolic inclusion' (Porter and Craig; 2004; Sager, 2011).

The current operating environment of planning practice in England has also been subject to a well-developed critique of the impacts of neo-liberal planning forms (Sager, 2011; 2009; Davoudi and Madanipour, 2013) and concerns over a depoliticisation effect have been rehearsed (Ghose, 2005; Brenner et al, 2010; Hall, 2011; Allmendinger and Haughton, 2012) whence those with power and resource maintain a critical degree of control (Newman, 2014; Neilson and Rossiter, 2008). In short the planning system, and present planning structures in England at least, appear to do little to rebalance access to knowledge and support towards those that need it most, despite rhetorical claims from UK governments that may indicate otherwise:

'many people may feel excluded in such a system because the process appears bureaucratic and forbidding, and because it seems too difficult and expensive to obtain legal information or advice. By simplifying processes, with clear opportunities 
for community involvement, we create [sic] a more effective, efficient and userfriendly service' (ODPM, 2004: p9).

This was taken from the high point of the New Labour efforts to induce particular forms of participation. Subsequently a form of 'localism' has been packaged and presented since 2010 in England, as 'empowering' but many regard this and the main vehicle, neighbourhood planning, as another constituent element of the neo-liberal tools and features being created to choreograph planners and the public (Sager, 2011; Clarke and Cochrane, 2013; Corbett and Walker, 2013; Newman, 2014; Baines et al., 2014). Wider factors, including streamlining of the planning system, austerity cuts which reduce public sector capacity, privatisation and a variety of performance management measures are implicated and deployed as part of a longer trend in reorienting planning (see Sager, 2011).

The recent iterations require self-help in planning activity but within a circumscribed space which avoids agonistic challenge (Parker et al, 2015; Bradley, 2015). This approach is justified by neo-liberal communitarians on the basis that agents can operate more effectively as rational actors in a market. This also bears certain assumptions about the willingness and capacity of individuals to participate (Conservative Party, 2010; Davoudi and Madanipour, 2013). As such the environment of increasingly neo-liberalised planning can marginalise minorities, or those lacking voice. While the aim to reverse or rebalance priorities for planning practice has underpinned the advocacy model promulgated by Davidoff (1965) and others (see, for example; Mazziotti, 1974; Sandercock, 1998), widespread advocacy and effective support is so far largely unattained, despite the best efforts of largely voluntary NGOs such as Planning Aid England, Planning Aid London, Planning Aid Scotland and Planning Aid Wales which remain constrained by resources, support and reach. Indeed more recent trends appear to make this prospect seem more distant.

Arguments to justify advocacy planning or 'equity planning' (Forester, 1994; Krumholz and Forester, 1990; Hoch, 1994), has received some renewed energy in an era of neo-liberalised planning and this is discernible in recent discussions over forms of 'insurgent' planning (Holston, 1998; Miraftab, 2009; Friedmann, 2011; Gualini, 2015). The advocacy planning movement was initially prompted by a concern with 'unjustifiable' inequitable outcomes associated with rational planning (Altshuler, 1965; Gans, 1982; Hoch, 1994) and where policy selection was seen to be embedded in the political process (Krumholz, 1994: p150) 
and which therefore needed to be opened up and 'recentred'. It was Paul Davidoff (1965) who reflected widespread concerns about inequalities of access to decision-making processes and the seemingly unjust outcomes wrought by urban renewal schemes in the 1950s and 1960s in his call for advocacy. Altshuler (1965) also argued that the plans made by professional planners were themselves selectively adopted by other powerful agents 'when the powerful use these plans, it is often to achieve the insidious goal of justifying private and political interests as public goods' (Hoch, 1994: p274). This led to consideration of how to deal with the reality that planning policy and outcomes were as much reflections of political and economic power as technical, rational expressions of the public interest (Benner and Pastor, 2015). The solution was to reveal this and challenge the powerful regarding their assumptions and claims to representativeness. Davidoff's (1965) perspective still resonates today:

'The recommendation that city planners represent and plead the plans of many interest groups is founded upon the need to establish an effective urban democracy, one in which citizens may be able to play an active role in the process of deciding public policy. Appropriate policy in democracy is determined through a process of political debate. The right course of action is always a matter of choice, never of fact. In a bureaucratic age great care must be taken that choices remain in the area of public view.' (Davidoff, 1965: p424).

Articulate and powerful groups have the resources and ability to mobilise relevant skills and influence to shape city plans to serve their own interests. Davidoff and others, such as Mazziotti (1974), argued that many do not have such capacities, or at least that such capacities or needs cannot be brought to the table without support or direct advocacy. Advocacy theory called on professional planners to act to champion the interests of those who were marginalised and Peattie (1978: p88) identified three forms of advocacy planning that had emerged in the US; the first being the classic advocacy form where 'desirable processes of change are arrived at by a more inclusively pluralistic political process'. The second is an activist strand which, while viewing modifications of policy and outcome deriving from the classic approach as desirable, regards the 'true' aim of advocacy to be the raising of 'radical consciousness and organisational competency' - often labelled as capacitybuilding. The third is a radical iteration whereupon 'radical political change in the base of society is necessary' and where, so the argument runs, advocacy can assist in that. Such distinctions and overlaps were also recognised by Sandercock (1998) when reflecting on the variety of styles of planning that emerged after the 1960s in recognition of a need to embrace the challenge of more inclusive empowerment in planning praxis. 
Critiques of subsequent theorisation of collaborative planning forms, and potentially some of the classic advocacy, see a danger in such models bargaining away or concealing different needs or preferences (Gunder, 2010; Agger and Løfgren, 2008; Neuman, 2000). Professional planners were in part 'needed to educate the community, to communicate and to translate the increasingly technical language of professional planning' (Heskin, 1980: p57). Lane (2005: p293) highlights that advocacy planning, as theory at least, also looked to 'unsettle' the planning system, with the following aims:

'to ensure that unheard or invisible interests were articulated and, as far as possible, accommodated in decision-making. Implicit in the approach is the rejection of the notion of a unitary public interest. Beginning with the assumption of political plurality, advocacy planners are essentially facilitators whose central task is to either catalyse the participation of inarticulate actors or, alternatively, advocate their interests directly'.

The type of urban democracy envisaged by Davidoff has had influence on the consideration of dialogics and agonism featured in the work of theorists such as Chantal Mouffe (e.g. 1999; 2005 ; 2007) and are based on the assumption of a more developed pluralist participatory democracy which implies a more partisan role for planners. Yet the effectiveness of the forms and episodes of advocacy planning practiced since the 1970s (e.g. Mouffe, 2005; Bailey, 2010; Haughton and Allmendinger, 2013; Checkoway, 1994; Forester, 1994; Peattie, 1968; 1978 ; 1994) remains questionable and issues remain regarding agonistic pluralism (see Gualini, 2015; Hillier, 2002) and where and how to deploy relevant models or combinations of apparently conflicting planning theory in suitable post-collaborative formulations (Benner and Pastor, 2015).

Friedmann (1987) identified that some advocacy planning activity could be seen as forming 'guidance' as opposed to more radical 'transformative' planning activity. For the latter to occur he argued that a more fundamental shift in the relationship between planners and 'clients' needed to take place - where the client becomes an active partner in planning (Friedmann, 1973: p172). He also noted the difficulties of reconciling advocacy in action with notions of the public interest which is 'constructed through political debate and even conflict' and this remains 'the master of social processes and the final goal of planning in the public domain' (Friedmann, 1987: p441). The distinction between guiding and transforming activity forms a useful heuristic when we consider the Peattie (1978) categories and the key 
issues that have followed in advocacy generally and given the influence of collaborative planning theory over the past two decades.

In the UK numerous efforts to respond to claims of elitism, anti-democratic behaviour and spatial injustice were triggered in the 1960s and this produced a legacy of planning practice critique which still echoes loudly today. A more inclusive and open type of planning was increasingly viewed as a political necessity, and was reflected, if weakly, in accommodations for participation opportunities in the 1970s (see, for example; Parker and Doak, 2005; Brownill and Carpenter, 2007b; Monno and Khakee, 2012). In parallel ideas about how an independent organisation, beyond governmental interest or control, such as Planning Aid, could act as an advocate for those otherwise unable to access the necessary specialist skills, knowledges and resources needed to engage in planning issues effectively. As discussed below the tensions apparent in advocacy and the Planning Aid experience thus far centres on five overlapping issues:

i. difficulty of reaching and selecting client groups or individuals for support;

ii. the danger of limited or qualified/conditional support;

iii. the possibility of limited horizons being offered up by advocates (i.e. the 'classic' variant of advocacy);

iv. a lack of organisation, capacity building effort and infrastructure to create selfsustaining activist communities; and

v. a lack of resources to challenge elite or dominant interests effectively.

Advocacy approaches include addressing the immediate needs of those who are excluded and who may suffer spatial and environmental injustices. The representation and defence of the interests of those who are under-represented and a desire to capacity-build through education and other means of support are together a central part of what we term a 'neo-advocacy' approach that responds to need for locally and temporally appropriate hybrid responses and which retain a critical degree of independence from centres of power. This term reflects a fluid hybrid of equity planning, transactive planning and the three advocacy forms; the hypothesis being that such an approach can result in a nurturing of voice, capacity and challenge. The neologism also reflects a recognition that support for a renewed advocacy is needed just as much now, if not more, than in the conditions of the 1960s. As part of the argument for such a model, the paper contributes to the debate about where Planning Aid 
does, could or should feature in the landscape of such a neo-advocacy planning offer by reflecting on current conditions and past experience.

The literature discussing advocacy, 'equity' and empowerment planning models (Krumholz and Forester, 1990; Krumholz, 1982; Peattie, 1978) has been largely hortatory and belies much of what we know about the difficulties in realising progressive planning forms and outcomes (see Matthews, 2013; Rydin, 2013). The focus has rested on the theory, design, technique and process (Sandercock, 1998), rather than the conditions necessary for success. Our view is that if (neo)advocacy planning forms are to be embraced the latter needs to be recognised.

\section{Planning Aid and Advocacy in England}

Planning Aid in England was championed by professional planners in England (see RTPI, 2013; Amos, 1971; Curtis and Edwards, 1980) and early Planning Aid groups in England operated with self-determined agendas prompted by advocacy theory and as circumstances and resources dictated. A feature of the Planning Aid project is that staff and volunteers have sought to provide assistance freely to those without the means to marshal their own interest effectively i.e. those who are inhibited from engaging in planning, and attempting to assert a new advocacy role for planners. The proponents of Planning Aid in England in the early 1970s set themselves a lofty set of transformative aims; ostensibly to empower those who lacked the means to participate effectively in shaping their own environment and to contest rational top down planning processes. Curtis and Edwards (1980:p3) highlight that in the first decade of Planning Aid there was no general understanding of what it involved except that it was 'concerned with enabling the public to have greater influence over planning decisions'. Subsequently the stated aims of Planning Aid England (PAE) have been expressed as follows: 'Planning Aid England offers planning advice and support to individuals and communities. We believe everyone should have the opportunity to get involved in planning their local area and provide people with the knowledge and tools to achieve this' (Planning Aid England/RTPI, 2015: no pagination).

We discuss how the aims of Planning Aid and its early exponents are still relevant but a consistent theme throughout the history of Planning Aid relates to the unease with which the planning polity has viewed advocacy and indeed any spaces which encourage challenge or agonistic exchange. Indeed any institutional arrangement which may destabilise an urban 
politics is likely to be regarded with suspicion, particularly where time and other resources are claimed to be scarce on a practical level, and which also reflects how urban planning remains 'a crucial site of political struggle' (McCann, 2001: p207). The political and institutional context in which Planning Aid has operated highlights the practical but fundamental issues that have dogged 'classic' and 'activist' advocacy in the UK given the way that the role and purpose of planning has been reshaped and given that 'other betterendowed groups are already busy with advocates of their own' (Friedmann, 1987: p300), in reference to private sector agents lobbying for those who can afford their services.

A segment of planning professionals, concerned with the inequitable outcomes with which they felt complicit, wanted to support, inform and empower those disenfranchised by the operation of the system in England. This provoked a response from the profession and as early as 1971 the then Royal Town Planning Institute president Jim Amos formally called for the establishment of a 'planning aid' service in England (Amos, 1971). Not long afterwards it was the Town and Country Planning Association (TCPA) who established the beginnings of a service in 1973 based in London (RTPI, 2013; Hardy, 1991). This was set up on an 'experimental basis...to make available a free independent source of planning advice' (Curtis and Edwards, 1980: $\mathrm{p} v$-vi). They received some modest funding from central government, ostensibly to redress the imbalance of access to planning processes.

While the early years of Planning Aid saw most activity in London and the South-East of England, various English regions and Wales (1978) and Scotland (1993) subsequently established separate Planning Aid services, with London retaining a service apart from the latterly RTPI-led Planning Aid England (see Evans and Gardiner, 1985). Northern Ireland also operated a service between 2000-2004 and the recent reorganisation of local government and the planning system there acted as a prompt for calls to re-establish a similar service once again (see Peel, 2013). A series of sympathetic critiques of Planning Aid expressed as early as 1980 (Curtis and Edwards, 1980); Bidwell and Edgar (1982) and Evans and Gardiner (1985); Thomas (1992) and Allmendinger (2004) highlight obstacles to the expansion or consolidation of Planning Aid. Indeed Curtis and Edwards (1980: pvi) state that the early service had found it challenging to reach its intended beneficiaries: 'the users of the service have not been those for whom it was designed, and whom, we agree, should receive the greatest priority'. Other published work on Planning Aid covers overviews of operational practices across the UK (Mordey, 1987; see also Pemberton et al, 2015); analysis from the 
perspective of volunteers and their rationales (Thomas, 1992) and the actual impact of Planning Aid on communities, the possible masking of deeper faults in the planning system (Allmendinger, 2004; 2002) and discussion of specific case studies (Hardy, 1991). More recently research explored how Planning Aid functioned, and who it was reaching during the first terms of the New Labour era (1997-2005) (see Brownill and Carpenter, 2006; 2007a,b).

The history of Planning Aid has seen different types of support activity offered and the longevity of Planning Aid has meant that the name has become recognised as a feature of planning practice in the UK. A wider advocacy planning offer has not been stabilised or embedded as a necessary part of a progressive planning system though and it is clearly not sufficient to rely on uncoordinated and unsupported local action groups to maintain their own responses alone. Campaigning groups such as Just Space in London (see Taylor and Edwards, 2016) exist and their modality may bear some resemblance to activist advocacy forms, but these seem exceptional. As such they may be regarded as laudable but are unlikely to 'move the centre' of planning on their own (Krumholz, 1994).

Prior accounts of Planning Aid by Bidwell and Edgar (1982), refined by Thomas (1992) and also expressed by Peel (2013) also identified several roles for Planning Aid which map in some measure across with Peattie's typology, these were: to provide advice, fulfil a responsibility as public educators, act as direct advocates and to perform a more fundamental community development role. It may be argued that the latter two are the most important approaches for transformative effect but have actually tended to form the minority part of Planning Aid England activity over time and it is advice and education that has been more dominant (Curtis and Edwards, 1980: p3; Thomas, 1992; Brownill and Carpenter, 2006). Throughout the history funding has been an overriding issue and has frustrated and oriented activity.

By the late 1970s, Planning Aid in England through the TCPA unit, and nascent groups across England, had become agents for advocacy in one-off planning disputes, as well as offering an education service with volunteers working directly with community groups and individuals. This activity was supported by a small staff team and by 1979 central government were taking an active interest in how such services might be supported and extended; having provided a small grant to pilot the service in the mid-1970s. The model appeared to hold potential to provoke a wider participation in local planning but there were 
recognised challenges as highlighted above (Curtis and Edwards, 1980). While some individual cases that Planning Aid volunteers and staff have pursued are notable, for example the case of the Divis Flats in Belfast and Tolmers Square, London (see Hardy, 1991), these appear to be somewhat exceptional as activist examples.

Soon after such incidences the TCPA planning aid unit was effectively dismantled by the withdrawal of government funding in the mid-1980s (Hardy, 1991). Despite such setbacks Planning Aid has expanded and diversified in the following decades to form the mainstay of the advocacy offer, and the response of the profession in the UK. Although it should be noted that individuals and local action groups have also attempted to challenge the planning system by applying advocacy theory in an ad hoc way (see Hardy, 1991; Friedmann, 2011). The uneven and often conditional support and funding for Planning Aid has influenced a range of cultures and operating conditions for the various Planning Aid organisations across the UK. They have developed slightly different structures, staff/volunteer mixes have also shaped their operation and focus over time.

While the skills and experience of volunteers and staff have been honed, and few would claim that Planning Aid cannot deliver positive outcomes in advocacy activity in principle, it is arguable whether the service in England has actually been able to achieve much in this regard. Given the close relationship between central government funding, when governmental goals were deemed congruent with Planning Aid skills and general outlook, PAE has sought to mutually align with government objectives as discussed below. This has made it more challenging still to deploy advocacy any of the three forms featured in the Peattie (1968; 1978) typology, as explained below and has left a rather limited legacy.

\section{Planning Aid England and New Labour}

The New Labour governments (1997-2010) claimed to recognise deficiencies in previous attempts to involve the public in planning. In reforming the planning system in their second and third terms in power (2001-2010), they sought to widen and organise participation (Parker and Doak, 2005). The 2004 Planning and Compulsory Purchase Act featured the 'frontloading' of community involvement in plan-making (ODPM, 2004: p10). Central government saw Planning Aid as a potential partner in helping to realise their intent and made explicit mention of the service. Moreover the 2004 prospectus on community 
involvement also aimed to address the engagement of previously excluded groups. As a result, Planning Aid England was funded by central government between 2005-2010 to deliver a programme of outreach and education this enabled the organisation to expand their activity and staffing levels.

The partnering arrangement between the New Labour governments and Planning Aid England came closest to institutionalising Planning Aid and allowed for some advocacy (via casework). Yet much of the activity encouraged by government fell into the 'advice' and 'education' categories, involving staff and volunteers promoting planning, informing people about the system and how they could be involved in it. There was perhaps less emphasis, by central government, on establishing whom should be the recipients of Planning Aid's support. This period saw the use of means such as roadshows, events and school visits to engage communities in planning facilitating and led by a large cadre of staff (around 60 people were employed by Planning Aid England at its peak). Another significant change was the development of a large cadre of volunteers during the 2000s; by 2012 the number of registered volunteer planners associated to Planning Aid England stood at around 900.

Difficulties in reaching target groups and mobilising and sustaining activity has been a longterm issue however, and Brownill and Carpenter (2006; 2007a) claimed this was the case even when levels of funding for Planning Aid was significant and the service extended across the whole of England. They also highlighted how the stability of Planning Aid in England had been reliant on grants and project funding.

A concern for many staff and volunteers was policy and operational 'drift' from Planning Aid's advocacy planning roots. Planning Aid volunteers and staff identified in interview that it was reaching deprived communities with their knowledge that was particularly motivating for them:

'helping disadvantaged communities is a key theme in engaging volunteers, when you talk to people [volunteers] they say actually that's why they come into the game in the first place; because they want to make a difference' (PAE volunteer, s04)

'I think the purpose of Planning Aid is really to support those that can't get support elsewhere...it did drift, certainly when I was involved, into helping groups that could afford to help themselves. If you think about the roots of Planning Aid...the Advocacy Planning, that's a very important [thing]' (PAE Volunteer, s05)

The volunteer role has often been to work with individuals or groups on a pro bono basis; typically on objections to planning applications or between 2010-201 to support 
neighbourhood planning groups (see Parker and Salter, 2016). While the staff role in supporting and maintaining the volunteer force is a critical one, Planning Aid staff interviewed stressed that many of the volunteers did not regularly involve themselves in case work. Internal work to understand the preferences of volunteers conducted in 2013 showed that some of the more challenging aspects of PAE's scope was seen as daunting for many volunteers (Staff Interview s02) and this sets up a question of whether volunteers alone can realistically be expected to pursue cases that may be lengthy and conflictual - not unless there is substantial support.

Writing just after the funding agreement between Planning Aid England and the Labour government had been concluded in 2003, Allmendinger (2004: p270) claimed that: 'what Planning Aid does is postpone crises in and challenges to...planning...by helping assure those dissatisfied or excluded from the system that they eventually had a 'voice' or a 'fair say". He was voicing doubt about how the rather limited service available could actually reform planning process and outcome in the spirit of the advocacy planning movement. This concern recurred in our research when discussing Planning Aid with volunteers and staff in relation to the West Midlands. Moreover the assumption made by Allmendinger (2004), that Planning Aid was actually performing an 'assurance' role, or more meaningfully supporting those dissatisfied or excluded, is not actually sustained by the evidence - even if the theoretical assertion may have carried weight if such activity had been delivered.

\section{Planning Aid in the West Midlands and Planning Aid England 2010-2016}

Planning Aid was mooted as early as 1976 in the West Midlands, with a service being formally offered by 1978 (RTPI, 2013; Curtis and Edwards, 1980: p54) and there has been a volunteer group delivering support to communities with planning issues across the region ever since - although the administrative arrangements have changed over time. The West Midlands region is broadly representative of England as whole with around $10 \%$ of the population of England located there and spread across a diverse array of 30 local authorities, although $25 \%$ (1.3 million) of the region's population were in households with incomes below the poverty threshold; one of the highest percentages of all English regions (ONS, 2011).

At its high point during the New Labour period the West Midlands had a dedicated team of Planning Aid staff. By 2011 the support for wider education and advice activity under New 
Labour had been cut. This resulted in an organisational shake-up and PAE staffing in the West Midlands region was reduced to one person, plus a basic centralised support service providing telephone advice from London. The minimal level of core funding made available from the RTPI (around $£ 140,000$ per annum in 2013) meant that PAE could not realistically deliver the kind of outcomes hoped for in the past and given there was little resource available for support, training, orchestration and direction this also affected the way that volunteers could be mobilised. The feeling of those staff interviewed was that priority groups were being neglected and that neighbourhood planning had largely supplanted other activity by 2012 .

One PAE staff interviewee acknowledged that the lack of Planning Aid staff meant that regional knowledge and expertise was also lost and opportunities for Planning Aid to perform useful work in the regions was not being identified or pursued. Overall PAE operated its service on a reactive model; responding to the requests of those who approached the service and then largely to give advice, or in the latter period to support neighbourhood planning.

'while PAE has wanted to support those in most need during my time working here, other activity has taken precedence, largely because of funding arrangements and prevailing conditions. It has meant that the advice and casework service that remained in the period 2011-2015 was reactive and many of those making use of it probably could have sought advice or support elsewhere - either from the local planning authority or from a consultant' (PAE Staff member, s02).

Work with the most deprived or other minority groups in society has proved challenging and there is little evidence about how the activity of PAE has addressed this in the past 20 years or so. In the West Midlands there were five case work instances taken up in 2014-15 and findings reported in 2006 also suggested that Planning Aid England had been responding largely to people who already had some knowledge of the planning system and only a relatively few of those were from disadvantaged groups:

'even with the sustained efforts the organisation's community planners are putting in to increase participation, barriers still exist... only a small percentage of community groups worked with were from black and ethnic minority groups. Similarly a large number of telephone callers to the Planning Aid information lines did not meet Planning Aid's criteria for assistance, which exclude those who can afford to pay for professional support' (Brownill and Carpenter, 2007b: p630).

Thus if these challenges were apparent then, the scope to address this was much reduced by 2011. The then new Coalition government had contracted PAE - after a competitive bidding 
process - to support neighbourhood plans, in the period 2011-2015, which were to be led by communities themselves and produced on the pre-condition that they accepted some growth (see Parker et al, 2015). Those active in the West Midlands felt a tension between the instrumental 'reality' of needing to find funds, set against the aims and integrity of the organisation which had interested them when they first became involved:

'I think that over the last few years, maybe the last 5 to 10 years Planning Aid has got lost. I think it has lost its mission and I think that hasn't helped matters. I think there is huge confusion about the role of volunteers.... Until we get a clear vision as to what we do, only then we can start talking about what volunteers do to help deliver that. For various understandable reasons there has been a bit of mission drift' (former PAE Staff member, s03).

The situation in the West Midlands reflects change across England where funding for Planning Aid England has been variously reduced, removed or shifted over time. Much of the concerns expressed by interviewees about the current and future orientation of Planning Aid in England related to the emphasis on neighbourhood planning. By 2015 Planning Aid England had supported 274 neighbourhood planning groups, with 40 of those located in the West Midlands. This soaked up considerable volunteer time working alongside the small number of paid staff involved in supporting those neighbourhoods. It emerged in focus group discussions with Planning Aid volunteers and staff that this was not necessarily seen as true to the historic mission. This was made more obvious given that so many early neighbourhood plans had been initiated by more affluent communities (see Gunn et al, 2015; Parker and Salter, 2016):

'I think the key thing is that Planning Aid needs to get back to dealing with people where there is a need...rather than focussing on areas like neighbourhood planning where there is money around...there is a need to get back to a variety of activities that focus on engaging people (in need) in all aspects of planning... (PAE volunteer, s05).

The challenge of returning to what several volunteers identified as Planning Aid's 'core mission' was rendered difficult largely due to funding. In interview a senior employee of Planning Aid England reflected that:

'the work of PAE in the period 2011 to 2015 rested predominately on neighbourhood planning, because this was where the funding was. We could only maintain a very limited operation beyond this due to the resources and capacity available. There was little space to challenge developers or local authorities on their actions or to look for cases or issues to pursue proactively' (PAE Staff member, s01).

'...the challenges were really twofold. The first was the demands of neighbourhood planning which took up almost all of the staff time and attention between 2011-2015. 
This meant that most volunteer activity reflected that priority. Some volunteers were not too happy about this and wanted to see a rebalancing [of activity] to assist those who needed planning support most. This brings into view the second challenge; relating to funding and a nervousness on the part of local authorities and consultancies about the historic aims of Planning Aid - as well as issues of conflict of interest if they supported the organisation financially, or for some even to volunteer for Planning Aid' (PAE staff member, s01).

Securing stable and adequate funding is a fundamental issue for any support organisation; let alone one that overtly aspires to enable advocacy planning. Finding appropriate and stable funding for Planning Aid has been a consistent issue across past reviews of Planning Aid, as underscored by Peel (2013: p2):

'it is important not to underestimate the costs involved in managing and sustaining a volunteer force. There is a need, for example, to recruit, coordinate, and support volunteers; and generally to promote and manage such a service in a professional way. As an RTPI-endorsed activity, the delivery of Planning Aid is reflective of the standards of the profession. The quality of the service - even if it is provided on a voluntary basis - is critical to the wider standing of the statutory land use planning system and how effectively, efficiently, and equitably it is perceived to operate' .

Funding is a recognised issue in the wider not-for-profit sector, where 'mission' is often seen to be in tension with organisational effectiveness and trade-offs between mission and organisational survival are common (Frumkin and Andre-Clark, 2000). This has rarely been given much attention in advocacy planning Corey's (1972) study of advocacy planning is an exception. Funding conditions attached and operating constraints associated with available funding are critical to the way organisations such as Planning Aid flourishes or orients itself. Indeed the overwhelming majority of the funding received by PAE since 2003 was shaped by governmental policy agendas, whether in the form of grant or project funds.

\section{Conclusion: embedding neo-advocacy in planning systems}

Successive reflections on Planning Aid performance highlight that the types of activity undertaken have been shaped by numerous constraints and obstacles; related to priorities of local and national politics, as well as the design and operation of the planning system overall and attendant funding constraints. Arguments in support of such activity and for Planning Aid in principle have not receded, but it has nevertheless been without the wherewithal to provide a more pervasive system of support. It is recognised how challenging it can be to enable and sustain inclusive participation in such environments (Eversole, 2012; Botes and Van Rensburg, 2000) and our exploration of Planning Aid's record raises serious doubts 
about both the reach and extent of work effected and the longer term influence on the communities supported. This corresponds with the mainstay of the critique levelled by Allmendinger (2004).

Indeed the account of PAE presented here can be viewed alongside an emerging narrative of how planning is being reshaped as a result of government spending cuts legitimated under the umbrella of austerity and reoriented through a growing reliance on privatised provision and other neo-liberal mechanisms. This set of structural issues is supplemented by substantive issues such as the chronic need for affordable housing (in the context of a housing crisis), the persistent gulf between incomes and quality of life, and the all too frequent poor-quality of new development (House of Lords, 2016), which together lend support to the argument that advocacy is needed more than ever by communities. While Planning Aid has lacked a clear framework for progressive action it appears it has never received unequivocal support from the state, or consistent support from within the planning profession either. On the basis of this experience, we argue that rather than abandoning advocacy the reverse is required and an 'arms-length' agency independent from local and central government to support and enable classic / activist advocacy i.e. which keeps challenge, capacity-building and advice core to its mission. It could be said this represents a 'neo-advocacy' for neo-liberal times and Bailey (2010: p319) developed a not dissimilar view: 'the traditional view is that community involvement can be added onto existing decision-making and service delivery bodies but increasingly it is being argued that these agencies need to be completely recast in order to give primacy to service users'.

This approach may have some prospect of addressing the five barriers and limitations to deploying advocacy via Planning Aid:

i. difficulty of reaching and selecting client groups or individuals for support this relates to confidence, resourcing as well as training and understanding within the cadre of advocates to ensure that identification and liaison is pursued;

ii. the danger of limited or qualified/conditional support - this is affected crucially by the question of independence and closeness to government in particular, and adds to the case for a separate adequately resourced and well managed body;

iii. the possibility of limited horizons being offered up by advocates (i.e. the 'classic' variant of advocacy) - again a question of training, inculcation of a neo-advocacy 'toolkit' and good management, as well as the points already made about (in)adequate funding; 
iv. a lack of capacity building effort and infrastructure to create self-sustaining activist communities - also perpetuated due to conditions of engagement being partly imposed by funders, as well as inadequate thought given to how to support and mobilise planning advocacy volunteers. This may also be alleviated by appropriate funding and continuity;

v. overall a lack of power and resource to challenge elite or dominant interests effectively - this is a critical issue and a lack of confidence among professional planners to act as advocates in current conditions and a weakened, fragmented profession exacerbates this.

This situation has meant that local authorities, themselves sometimes conflicted, and certainly constrained, struggle to call to account powerful and well-organised interests on the one side and fail to orchestrate meaningful inclusive participation on the other. Planning Aid provides a platform for action and institutional design, status and questions of consistent resourcing appear critical to us. This basic question of resourcing has never been adequately resolved. Moreover there has been no appetite to see a neo-advocacy mission embedded as a necessary feature of the planning system. The role for Planning Aid implied by the early proponents of advocacy planning is one that cannot be easily reconciled with current neo-liberal governmentalities as such a stable and independent Planning Aid role is becoming more not less important and neo-advocacy activity is needed to bolster collaborative forms in order to hold the system to account and provide needed balance - perhaps particularly so given the effective lobbying and advocacy role that the private sector plays in the system at present.

Planning Aid or whatever emerges in the coming years should mobilise communities to engage critically; to help people think and reflect as well as challenge and reorient planning. The presence of a stable institution that has as its main role neo-advocacy orientation that is not dogmatic but contextually relevant and nuanced in the light of participatory theory generated over the past forty years merits serious consideration. Such a body should also make creative use of techniques and opportunities afforded and explained through the legacy of various strands of participatory theory and in this way adopt a post-collaborative stance.

\section{References}

Agger, A. and Löfgren, K. (2008) 'Democratic assessment of collaborative planning processes'. Planning Theory, Vol. 7(2): 145-164.

Allmendinger, P. (2002) 'Planners as Advocates' pp133-154 in Allmendinger, P. Planning Theory. Palgrave Macmillan, Basingstoke. 
Allmendinger, P. (2004) 'Palliative or cure? Reflections on the practice and future of Planning Aid', Planning Theory and Practice, 5(2): 269-271.

Allmendinger, P. and Haughton, G. (2012) 'Post-political spatial planning in England: a crisis of consensus?' Transactions of the Institute of British Geographers, NS 37(1): 89-103.

Altshuler, A. (1965) The City Planning Process. A Political Analysis. Cornell University Press, Ithaca, NY.

Amos, J. (1971) 'Presidential address', Journal of the Royal Town Planning Institute, 57(9): 397-399.

Bailey, N. (2010) 'Understanding community empowerment in urban regeneration and planning in England: Putting Policy and Practice in Context', Planning Practice and Research, 25(3): 317-332.

Baines, D., Cunningham, I., Campey, J. and Shields, J. (2014) 'Not Profiting from Precarity: the work of non-profit service delivery and the creation of precariousness'. Just Labour: Canadian Journal of Work and Society, 22: 75-93.

Bengs, C. (2005) 'Planning theory for the naïve'. European Journal of Spatial Development, http://www. nordregio. se/EJSD/-ISSN, pp.1650-9544.

Benner, C. and Pastor, M. (2015) 'Collaboration, conflict and community building at the regional scale: implications for advocacy planning', Journal of Planning Education and Research, Vol. 35(3): 307-322.

Bidwell, L. and Edgar, W. (1982) 'Promoting Participation in Planning: a case study of Planning Aid in the Dundee area' pp.137-152 in Smith, L. and Jones, E. (eds.) Deprivation, Participation and Community Action, London: Routledge.

Botes, L. and Van Rensburg, D. (2000) 'Community participation in development: nine plagues and twelve commandments'. Community Development Journal, 35(1): 41-58.

Bradley, Q. (2015) 'The political identities of neighbourhood planning in England', Space and Polity, 19(2): 97-109.

Brenner, N., Peck, J. and Theodore, N. (2010) 'Variegated neo-liberalism: geographies, modalities, pathways'. Global Networks, 10(2): 1-41.

Brownill, S. (2009) 'The dynamics of participation: modes of governance and increasing participation in Planning', Urban Policy and Research, 27(4): 357-375.

Brownill, S. and Carpenter, J. (2007a) 'New improved participatory planning? The Planning Aid experience', Town and Country Planning, 76(1): 26-29.

Brownill, S. and Carpenter, J. (2007b) 'Increasing participation in planning: emergent experiences of the reformed planning system in England', Planning Practice and Research, 22(4): 619-634.

Brownill, S. and Carpenter, J. (2006) Evaluation of the National Planning Aid Service. RTPI, London. 
Brownill, S. and Parker, G. (2010) Why Bother with Good Works? The Relevance of Public Participation(s) in Planning in a Post-collaborative Era', Planning Practice and Research, 25(3): 275-282.

Checkoway, B. (1994) 'Paul Davidoff and Advocacy Planning in Retrospect', American Planning Association Journal, 60(2): 139-143.

Clark, J. (1991) Democratizing Development. The Role of Voluntary Organisations, Earthscan, London.

Clarke, N. and Cochrane, A. (2013) 'Geographies and politics of localism: the localism of the United Kingdom's Coalition government', Political Geography, 34: 10-23.

Cleaver, F. (1999) 'Paradoxes of participation: questioning participatory approaches to development' Journal of International Development, 11(4): 597-612

Cleaver, F., Cooke, B. and Kothari, U. (2001) 'Institutions, agency and the limitations of participatory approaches to development', pp.36-55 in Cooke, B. and Kothari, U. (eds) (2001) Participation: The New Tyranny? Zed Books, London.

Conservative Party (2010) Open Source Planning. Policy paper \#14. The Conservatives, London.

Corbett, S. and Walker, A. (2013) 'The Big Society: rediscovery of 'the social' or rhetorical fig-leaf for neo-liberalism?' Critical Social Policy, Vol. 33(3): 451-472.

Corey, K. (1972) 'Advocacy in planning: a reflective analysis’, Antipode 4(2): 46-73

Curtis, B. and Edwards, D. (1980) Planning Aid Occasional Paper No. 1. November 1980. University of Reading, UK.

Davidoff, P. (1965) 'Advocacy and pluralism in planning', Journal of the American Institute of Planners, 31(4): 331-338.

Davoudi, S. and Madanipour, A. (2013) 'Localism and neo-liberal governmentality' Town Planning Review, 84(5): 551-562.

Davoudi, S. and Madanipour, A. (eds.) (2015) Reconsidering Localism. Routledge, London.

DCLG [Department for Communities and Local Government] (2011) Plain English Guide to the Localism Act. November 2011. DCLG, London.

Evans, B. and Gardiner, H. (1985) 'Planning Aid: past and future'. The Planner, 71(7): 1013.

Eversole, R. (2012) 'Remaking participation: challenges for community development practice'. Community Development Journal, 47(1): 29-41.

Fainstein, S. (2010) The Just City. Cornell University Press, New York.

Forester, J. (1994) 'Bridging interests and community: advocacy planning and the challenges of deliberative democracy', Journal of the American Planning Association 60(2):153-158. 
Forester, J. and Krumholz, N. (1990) Making Equity Planning Work: Leadership in the Public Sector. Temple University Press, New York.

Friedmann, J. (2011) Insurgencies: Essays in Planning Theory. Routledge, London.

Friedmann, J. (1987) Planning in the public domain: from knowledge to action, Princeton University Press, Princeton, NJ.

Friedmann, J. (1973) Retracking America: a theory of transactive planning. Anchor, New York.

Frumkin, P. and Andre-Clark, A. (2000) 'When Missions, Markets and Politics Collide: Values strategy in the non-profit sector', Non-Profit Organisations and Voluntary Sector Quarterly, 29(1): 141-163.

Gans, H. (1982) Urban Villagers. Simon and Schuster, New York.

Ghose, R. (2005) 'The complexities of citizen participation through collaborative governance'. Space and Polity, 9(1): 61-75.

Gualini, E. (ed.) (2015) Planning and Conflict. RTPI/Routledge, Oxford.

Gunder, M. (2010) 'Planning as the ideology of (neoliberal) space'. Planning Theory, 9(4): 298-314.

Gunn, S., Brooks, E., and Vigar, G. (2015) 'The Community's Capacity to Plan: the disproportionate requirements of the new English Neighbourhood Planning initiative', pp. 147-167 in Davoudi, S. and Madanipour, A. (eds.) Reconsidering Localism. Routledge, London.

Hall, S. (2011) 'The neo-liberal revolution'. Cultural Studies, 25(6): 705-728.

Hardy, D. (1991) From New Towns to Green Politics: Campaigning for Town and Country Planning 1946-1990. E \& F.N. Spon, London.

Haughton, G. and Allmendinger, P. (2013) 'Spatial planning and the new localism'. Planning Practice and Research, 28(1): 1-5.

Healey, P. (2003) 'Collaborative Planning in Perspective', Planning Theory, 2(2): 101-123.

Heskin, A. (1980) 'Crisis and Response: A Historical Perspective on Advocacy Planning', Journal of the American Planning Association, 46(1):50-63.

Hillier, J. (2002) 'Direct action and agonism in democratic planning practice' pp.110-35 in Allmendinger, P. and Tewdwr-Jones, M. (eds.) Planning Futures: New Directions for Planning Theory. Routledge, London.

Hoch, C. (1994) What Planners Do. Power, Politics and Persuasion. APA, Chicago.

Holston, J. (1998) 'Spaces of insurgent citizenship' pp37-56 in Sandercock, L. (ed.) Making the Invisible Visible: a Multicultural Planning History. University of California Press, Berkeley. 
House of Lords (2016) Building Better Places. Select Committee on National Policy for the

Built Environment, February 2016. TSO, London. Located at:

http://www.publications.parliament.uk/pa/ld201516/ldselect/ldbuilt/100/100.pdf [last accessed 18 July 2016]

Huxley, M. and Yiftachel, O. (2000) 'New paradigm or old myopia? Unsettling the communicative turn in planning theory'. Journal of Planning Education and Research, 19(4): 333-342.

Krumholz, N. (1994) 'Advocacy planning: can it move the center?' Journal of the American Planning Association, 60(2): 150-151.

Krumholz, N. (1982) 'A retrospective view of equity planning in Cleveland 1969-1979'. Journal of the American Planning Association, 48(2): 163-174.

Lane, M. (2005) 'Public participation in planning: an intellectual history', Australian Geographer, 36(3): 283-299.

MacDonald, K. (2014) 'Professional planning 100 years on - have we emancipated communities?' Planning Theory and Practice, 15(1): 95-100.

Matthews, P. (2013) 'The longue durée of community engagement: New applications of critical theory in planning research'. Planning Theory, 12(2): 139-157.

Mazziotti, D. (1974) 'The Underlying Assumptions of Advocacy Planning: pluralism and reform', Journal of the American Institute of Planners, 40(1): 38-47.

McCann, E. (2001) 'Collaborative visioning or urban planning as therapy? The politics of public-private policy making', The Professional Geographer, 53(2): 207-218.

Miraftab, F. (2009) 'Insurgent planning: Situating radical planning in the global south'. Planning Theory, 8(1): 32-50.

Mitlin, D. (2008) 'With and beyond the state: co-production as a route to political influence, power and transformation for grassroots organizations'. Environment and Urbanization, Vol. 20(2): 339-360.

Monno, V. and Khakee, A. (2012) 'Tokenism or political activism? Some reflections on participatory planning'. International Planning Studies, 17(1): 85-101.

Mordey, R. (1987) 'Development control, public participation and the need for Planning Aid' pp195-216 in Harrison, M. and Mordey, R. (eds.) Planning Control: philosophies, prospects and practice. London, Croom Helm.

Mouffe, C. (1999) 'Deliberative democracy or agonistic pluralism?' Social Research, 66(3): 745-758.

Mouffe, C. (2005) On the Political. Routledge, London.

Mouffe, C. (2007) 'Democracy as agonistic pluralism', pp36-45 in Rewriting democracy: cultural politics in postmodernity, Ermarth, E. (ed.) Ashgate, Aldershot. 
Neilson, B. and Rossiter, N. (2008) 'Precarity as a political concept, or, Fordism as exception'. Theory, Culture \& Society, 25(7-8): 51-72.

Neuman, M. (2000) 'Communicate this! Does consensus lead to advocacy and pluralism?' Journal of Planning Education and Research, 19: 343-350.

Newman, J. (2014) 'Landscapes of antagonism: local governance, neo-liberalism and austerity', Urban Studies, 51(15): 3290-3305.

ODPM [Office of the Deputy Prime Minister] (2004) Community Involvement in Planning. ODPM, London.

ONS [Office of National Statistics] (2011) Portrait of the West Midlands. ONS, Fareham.

Parker, G. and Doak J. (2005) 'Networked space? The challenge of meaningful participation and the new spatial planning in England', Planning Practice and Research, 20(1): 23-40.

Parker, G., Lynn, T., and Wargent, M. (2015) 'Sticking to the script? The co-production of neighbourhood planning in England'. Town Planning Review, 86(5): 519-536.

Parker, G. and Salter, K. (2016) 'Five years of neighbourhood planning: a review of take-up and distribution'. Town and Country Planning, 85(5): 181-188.

Parker, G. and Street, E. (2015) 'Planning at the neighbourhood scale: localism, dialogic politics and the modulation of community action'. Environment and Planning ' $C$ ': Government and Policy, 33(4): 794-810.

Parker, G., Street, E. and Wargent, M. (forthcoming) 'A framework for the analysis of private sector consultancy: accountabilities, motives and roles in a fragmented English local planning system' Territory, Politics and Governance (in press).

Peattie, L. (1968) 'Reflections on Advocacy Planning', Journal of the American Institute of Planners, 34(2): 80-88.

Peattie, L. (1978) 'Politics, planning and categories: bridging the gap' pp83-94 in Burchell, R. and Sternlieb, G. (eds.) Planning Theory in the 1980s. CUPR, New Jersey.

Peattie, L. (1994) 'Communities and interests in advocacy planning, Journal of the American Planning Association, 60(2): 151-153.

Peel, D. (2013) Planning Aid Northern Ireland: Scoping Study. June 2013. University of Ulster, Belfast.

Pemberton, S., Peel, D. and Lloyd, G. (2015) 'The 'filling in' of community-based planning in the devolved UK?' The Geographical Journal, 181: 6-15.

Piccolo, F. and Thomas, H. (2003) Knights and castles: Minorities and urban regeneration. Gower, London.

Pløger, J. (2004) 'Strife: urban planning and agonism'. Planning Theory, 3(1): 71-92. 
Porter, D. and Craig, D. (2004) The third world and the third way: poverty reduction and social inclusion in the rise of 'inclusive liberalism', Review of International Political Economy, 11(2): 387-423.

RTPI (2016) Support for Community-led Planning. RTPI research briefing No. 14 May 2016. RTPI, London.

RTPI (2015) 'Investing in Delivery: How we can respond to the pressures on local authority planning? RTPI Research Report No. 10, October 2015. RTPI, London.

RTPI / Planning Aid England (2015) Planning Aid England webpage: http://www.rtpi.org.uk/planning-aid/ [last accessed 15 December 2015]

RTPI (2013) Planning Aid 'timeline history' located at: http://www.rtpi.org.uk/planningaid/what-we-do/our-history/ [last accessed 15 December 2015]

Rydin, Y. (2013) The Future of Planning. Policy Press, Bristol.

Sager, T. (2011) 'Neo-liberal urban planning policies: a literature survey 1990-2010', Progress in Planning, 76: 147-199.

Sandercock, L. (1998) 'The Death of Modernist Planning: radical praxis for a postmodern age'. pp163-184 in Douglass, M. and Friedmann, J. (eds.) Cities for Citizens. Wiley, New York.

Soja, E. (2010) Seeking Spatial Justice. University of Minnesota Press, Minneapolis.

Tait, M. (2016) 'Planning and the public interest: Still a relevant concept for planners?', Planning Theory, 15(4): 335-343.

Taylor, M. (2007) 'Community participation in the real world: opportunities and pitfalls in new governance spaces’. Urban Studies, 44(2): 297-317.

Taylor, M. and Edwards, M. (2016) 'Just Space economy and planning', pp74-84 in Beebeejaun, Y. (ed) The Participatory City. Jovis, Berlin.

Theodore, N. and Peck, J. (2011) 'Framing neo-liberal urbanism: translating 'commonsense' urban policy across the OECD zone', European Urban and Regional Studies, 19(1): 20-41.

Thomas, H. (1992) 'Volunteers involvement in planning aid. Evidence from South Wales'. Town Planning Review, 63(1): 47-62. 